\title{
GEOPHYSICAL DAMAGE TO PROPERTY AND RELATED PROBLEMS*
}

Geophysical operations have, from their inception, presented a conflict between one person's right to use his proprietary interest in minerals as he wishes in the exploration for petroleum and natural gas, and another's right to enjoy his property without hindrance or molestation. The Courts have thus been torn between the utilitarian use of one's property, possibly resulting in vast economic and social benefits, and the preservation of one's right to the quiet enjoyment of one's property.

This paper first presents some of the judicial interpretations in instances of subsurface damage to an innocent party's land, with an attempt being made to show the trends in various jurisdictions and the legal basis for such trends.

The paper then discusses some possible problems which may arise with the dissemination of seismic information to other parties, who act upon the knowledge gained, to their benefit or detriment.

\section{SUBSURFACE DAMAGE*}

Oil Operator $\mathrm{C}$ hires geophysical company $\mathrm{G}$ to carry out a seismic survey. As a direct but unforeseeable result of G's operations a water well belonging to Farmer Jones is damaged to the extent that it will no longer function as a water well. The following questions arise:-

(i) Is G liable to Farmer Jones?

(ii) If $G$ is willing to pay the cost of drilling one new water well can Farmer Jones insist that $G$ is obligated to provide him with a new water well comparable to the damaged well?

(iii) What kind of evidence might satisfy a trier of fact that no causal relationship existed between the seismic shooting and any claimed damage to the well?

\section{A. LIABILITY}

A general review of the law relating to seismic damage to underlying strata ranges from a scattering of decisions in Canada to a dearth of authority in the United States. The jurisdiction where the action is commenced is a determining factor on the choice of a cause of action, the pleadings and, of course, the decision. The judicial reactions and resulting jurisprudence have been as varied as the proverbial coat of many colours. As one might expect, the decisions in the United States vary from state to state, each developing its own approach to the problems based on early mining and oil operating history. In Canada a lack of exposure to the problems combined with the few incidental cases which have been reported, leave the field fairly well open to any approach being adopted. The one Alberta case that has been reported ${ }^{1}$ dealing

- This paper was prepared through the combined efforts of Maury G. Van Vilet, Pan American Petroleum Corporation, Calgary; Bruno J. Todesco, Banff Oil Itd., Calgary; Donald C. Hetland, Atlantic Rlchfield Company, Calgary; John S. Moore, Standard Iimited, Calsary.

- This portion of the paper was written by Maury G. Van Vilet.

1 Phillips v. California Standard et al (1960), 31 W.W.R. 331. 
with similar facts certainly indicates a trend which future decisions in Alberta and the rest of Canada may well follow.

A plaintiff to succeed will first be concerned with how to frame his cause of action. As has been stated, the possibilities are governed to a large degree upon the jurisdiction in which the action is brought. Depending on the jurisdiction, negligence, trespass, nuisance and Rylands v. Fletcher ${ }^{2}$ have all been pleaded with success. Generally speaking, it is possible to separate the decisions into two categories; negligence and strict liability.

\section{New York Rule}

The so-called "New York Rule" is merely a rule of liability based on proof of negligence. ${ }^{3}$ The jurisdictions following this rule will only find liability if negligence can be shown on the part of the defendant. This, of course, is a tremendous disadvantage for the plaintiff who, in most instances, is in no position to prove negligent operation on the part of the defendant due to lack of knowledge of the defendant's method of operations.

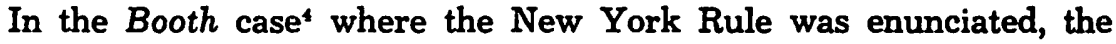
Court was concerned with damage to neighbouring land by the blasting operations of the defendant on his own property. The damage had been caused by vibrations and concussion and the plaintiff brought his action in nuisance. The Court in delivering its opinion stated:

But the defendant here was engaged in a lawful act. It was done on his land to fit it for a lawful business. It was not an act which, under all circumstances, would produce injury to his neighbour as is shown by the fact that other buildings nearby were not injured. The immediate act was confined to its own land; but the blasts, by setting the air in motion, or some other unexplained way, caused an injury to the plaintiff's house. The lot of the defendant could not be used for its roadbed until it was excavated and graded. It was to be diverted to a common use; that is, to a business use. The blasting was necessary, was carefully done and the injury was consequential. There was no technical trespass. Under these circumstances we think the plaintiff has no legal ground of complaint.

Texas, among other states, has rejected the concept of liability without fault and has indicated the necessity of proof of negligence. In the leading case of Klostermann v. Houston Geophysical Company the Texas Court of Civil Appeals for San Antonio dealt with damage to houses on adjoining property from seismic operations of the defendant. ${ }^{\circ}$ The court held:

The basic question before the court is whether in such operations Texas follows, or will follow, the rule of liability without fault or the rule of negligence. ... In our opinion there is no need for the rule of liability without fault ... to call seismographic operations hazardous everywhere and always does not make them so and does not prove the need for liability without fault on the operator.... We conclude that Texas is committed to the rule that seismographic operations fall within the tort field of negligence law and that the better reasons argue against our return to the ancient rule of liability without fault.

\section{Res Ipsa Loquitur}

In some jurisdictions such as Louisiana the doctrine of res ipsa loquitur has been pleaded and accepted by the courts. In such a case

2 The Rule of Law laid down in this famous English case is commonly referred to by this name: 37 L. J. Ex. 161.

3 This Rule was laid down in Booth v. Rome et al (1893), 35 N.E. 592.

4 Ibid. 315 .W. (2d) 664. 
the plaintiff merely shows an explosion with resulting damage and alleges negligent operation on the part of the defendant. This, of course, then places the onus on the defendant to show he was in fact not negligent. The leading case in Louisiana employing this rule is Hoyt $v$. Amerada Petroleum Corporation ${ }^{6}$ where the Court of Appeal dealt with the plaintiff claiming damages for injury to his water well after the defendant's seismic explosions. The contention that the doctrine of res ipsa loquitur should be applied was accepted by the court, which found that the defendant had failed to produce evidence sufficient to establish that the explosions were not the proximate cause of the damage to the well.

The result of the application of res ipsa loquitur is that, in effect, strict liability is applied against the operator. It is quite apparent that in negligence actions of this kind the party having the onus of proof invariably loses as, in most cases, negligence can neither be proven nor disproven. Jurisdictions applying res ipsa loquitur are few and the application of the doctrine has been expressly rejected in Texas.?

In the Lambert case ${ }^{8}$ the doctrine of res ipsa loquitur was applied by the trial court but was expressly rejected in the Court of Civil Appeals which held that there must be some proof of negligence before liability should be attached, and that negligence and proximate cause cannot be inferred merely from the fact of the explosion.

Of passing interest is an additional cause of action in the United States under the doctrine of implied covenants. The option of suing in contract rather than in tort arises where the property owner has an agreement with the seismic operator. In such a case the courts will imply a covenant to conduct operations with reasonable care. ${ }^{3}$

\section{Strict Liability}

The other approach to an operator's liability taken by a majority of oil and gas jurisdictions is that of strict or absolute liability. The philosophy behind the application of strict liability is well illustrated by a passage in Fleming, The Law of Torts: ${ }^{10}$

Strict liability is imposed on unlawful rather than reprehensible conduct. Certain types of activity, which involve extraordinary risks to others, either in the seriousness of the harm threatened or, more often, in its high degree of probability, are charged with the responsibility for insuring the ensuing harm, even if the most diligent care has been exercised to obviate its occurrence. In these situations, it is widely felt that he for whose benefit the risk is created should bear the loss unavoidably entailed rather than the random victim.

Absolute liability has found great favour in various parts of the United States and Canada. A typical statement from a court faced with geophysical damage occurs in Green v. General Petroleum Corp. ${ }^{11}$

Where one, in the conduct and maintenance of an enterprise lawful in itself, deliberately does an act under known conditions, and, with knowledge that injury may result to another proceeds, and injury is done to the other as a direct and proximate consequence of the act, however carefully done, the one who does the act and causes the injury, should, in all fairness, be required to compensate the other for the damage done.

6 3 Oil and Gas Reporter 296.

7 Stanolind Oil \& Gas Company v. Lambert, 222 S.W. (2d) 125.

8 Ibid.

9 Williams \& Myers, Oil \& Gas Law, Vol. 5, at 424.

$103 d$ ed., at 291 .

11270 Päcific 592. 
The old maxim of sic utere tuo ut alienum non laedes, which would allow a landowner to use his land as he saw fit, even to the detriment and inconvenience of his neighbours, has been brushed aside whenever the use of the landowner appears to be unusual.

The cause of action for geophysical liability is one of three types: trespass, the rule in Rylands v. Fletcher or nuisance. Most United States decisions adopting strict liability do not specifically mention nuisance or Rylands v. Fletcher, but rather refer to absolute liability as being a general category of broad scope. Some U.S. writers, such as W. D. Masterson, Jr. ${ }^{12}$ indicate that in many areas of an oil and gas operator's liability the courts have expressly rejected absolute liability based on Rylands v. Fletcher and the escape of, or damage caused by, things or operations inherently dangerous, only to apply the law of nuisance and, in the end, reach the same result. As Masterson points out, where Rylands v. Fletcher is applied the sole question to be answered then becomes whether or not the activity engaged in is inherently dangerous.

Several cases in the United States have held that the vibrations from blasting operations constitute a physical trespass just as if rocks or debris were thrown over the adjoining property. ${ }^{13}$ This theory, is however, not generally accepted. Most jurisdictions, including Canadian courts, have held that liability for blasting operations arises from the application of Rylands v. Fletcher or nuisance. These two causes of action are often very similar, but as indicated by Lord Wright sitting on the Privy Council in discussing Rylands v. Fletcher;

This form of liability is in many ways analogous to a liability for nuisance, though nuisance is not only different in its historical origin but in its legal character and many of its incidents and applications. But the two causes of action often overlap. ${ }^{14}$

The rule in Rylands v. Fletcher has been applied to operations causing vibrations in Canada, by the Ontario Court of Appeal, which had to deal with the claim by the plaintiff for damage to his house as a result of the defendant's operations. ${ }^{15}$ In this case Fisher, J.A. stated:

A person who starts and causes vibrations to escape is in much the same position as a person who brings water onto his own premises and allows it to escape.

\section{Nuisance}

Most actions for damage caused by vibrations from one source or another where the negligence of the defendant would be most difficult or impossible to prove, are based on nuisance; but nuisance and Rylands v. Fletcher may overlap as well illustrated by Aikman v. Mills \& Co., ${ }^{10}$ where the Ontario Supreme Court dealt with an action for damages from vibrations caused by the defendant's blasting operations. In giving judgment for the plaintiff Rose, J. C., stated:

If the blasting had the effect, which I think it has been proved to have had, a nuisance was created; also prima facie there is liability upon the doctrine of Rylands v. Fletcher, which applies in the case of vibrations set up and causing structural damage to buildings; Hoare \& Co. v. McAlpine (1923) $1 \mathrm{Ch}$. 167, even if the act causing the damage was done on land which the defendant did not own but only had the right to occupy for a particular purpose. ...

12 The Legal Position of the Drilling Contractor,

The First Annual Institute on Oil and Gas Law and Taxation, Southwestern Legal Foundation.

13 Watson v. Mississippi River Power Co., 156 N.W. 188.

14 Northwestern Utilities Ltd. v. London Guarantee and Accident Co., [1935] 3 W.W.R. 446.

15 Bower v. Richardson Construction Co., [1938] 2 D.L.R. 309; see also Plliterri v. Northern Construction Co., [1930] 4 D.L.R. 731.

10 [1934] 4 D.L.R. 264. 
Perhaps the leading case in Canada dealing with vibrations as a nuisance is Dufferin Paving \& Crushed Stone Ltd. v. Anger \& Derbyshire ${ }^{17}$ which was decided by the Supreme Court of Canada. In that case the plaintiff brought an action for nuisance as a result of damages to his home caused by the vibrations from the passage of large cement trucks of the defendants. The decision was decided on another point; however, three of the five judges indicated they agreed with the majority of the Ontario Court of Appeal that the vibrations set up by the trucks constituted an actionable nuisance.

The only decided cases in Western Canada involving property damage resulting from seismic vibrations are Phillips v. California Standard Company ${ }^{18}$ and Reilly v. Pan American Petroleum Corp. ${ }^{10}$ In both of these cases the plaintiffs' water wells had been damaged by seismic explosions on adjoining lands.

In the Phillips case the action was brought in trespass, as is the practice in some United States jurisdictions. Commenting on this Riley J. noted:

The plaintiff bases his action, both in his pleadings and in his argument, on the ground of trespass. I have'grave doubts that the defendant's seismic operations on the road allowance amounted to a trespass. In England and Canada trespass involves a physical entry on the property of another and in the case at bar that physical entry never took place.

I am of the opinion that vibrations set up by the defendant and transmitted to land occupied by the plaintiff, do not in law constitute a trespass, but do in law, give a cause of action in nuisance.

Riley J. also quoted with approval a passage from Pollock on Torts, 15th ed. at 337, which seems to reject the application of Rylands v. Fletcher to cases involving vibrations:

In Hoare \& Co. v. McAlpine, Astbury, J. accepted a suggestion, not necessary to the decision, that the rule extends to vibrations set up in the soil by pile-driving (with the consequence of all damage therefrom being recoverable whether it amounts to nuisance or not); but this seems a fallacious extension. A man cannot be said to bring or collect vibrations on his land, nor can they be said to be stored or allowed to escape; neither are they noxious or dangerous in their own nature. On principle a cause of action is nuisance or nothing, and no authority can be shown for inventing any other.

With respect to the evidence introduced by the plaintiff, Riley $\mathrm{J}$. declared:

The evidence is overwhelming and overpowering linking the plaintiff's loss with the defendant's explosions, the vibrations of which would extend a mile deep and horizontally for some twenty-four hundred feet. The strata injury from the shot or shots need not necessarily have occurred in the immediate vicinity of the well in question and may have occurred some distance from the same, but the shots undoubtedly did cause strata damage which affected the well's production. Obviously, there was a strata injury beneath the plaintiff's farm, probably caused by the intensity of the seismic explosions, and it is noteworthy that the quantity and quality deterioration in the plaintiff's well water commenced only after the explosion set off by the defendant. The production from the plaintiff's well was reduced almost to zero.

In the Reilly case the flow of the plaintiff's artesian well was severely reduced following several seismic shots performed by the defendants. Kirby, J. quoted the Phillips case with approval and added:

... I am of the opinion that the vibrations set up by these explosions and transmitted to the strata supplying the flow of water through this artesian spring

17 [1940] 1 D.L.R. 1.

$18(1960), 31$ W.W.R. 331.

19 See Lewts and Thompson, Canadian Oil \& Gas, Vol. 1. Dig. 213, not otherwise reported; Supreme Court Action 69939; Calgary. 
situated on the defendant's lands do in law give a cause of action for nuisance. The evidence with regard to trespass is not sufficiently conclusive, in my opinion to make a finding, but I am satisfied that the plaintiffs do have a cause of action in nuisance.

It would thus certainly appear that in Alberta the courts favour nuisance as a cause of action for these types of physical property damage. There is, however, a great deal of latitude for future decisions of the Appellate Division of the Supreme Court of Alberta and the Supreme Court of Canada. The decisions reached by our courts must reflect some sound economic and social considerations where liability is to be determined. The philosophy of this judicial dilemma is discussed by Professor W. L. Summers who seems to favour absolute liability on the part of the operator: ${ }^{20}$

It is not easy to draw a line prescribing the limits within which a landowner may legally use his own land for a lawful and utilitarian purpose. That it is a matter of great social and economic importance to discover and develop the mineral resources of any state or locality is not to be questioned, and the law should encourage rather than hinder such activity. But on the other hand, it is a rule of sound social policy that the owners and occupiers of lands in the vicinity of oil explorations should not suffer the destruction of their property and injury to their persons by the methods used therein. In balancing the conflicting interests of the parties in similar situations the courts, whether they so express it or not, give much weight to the utility of the alleged wrongdoer's act as against the alleged injury to the neighboring owner. Many inconveniences and injuries to land or its use are unredressed in order that all may enjoy certain compensating conveniences. Where, however, a landowner in the use of his land or in fitting it for lawful use causes actual physical disturbance to his neighbor's land resulting in injury to property or person, the utility of such use cannot make it a privileged one. It is submitted, therefore, that where one explodes a charge of dynamite to test his land for oil and gas purposes and thereby causes the earth to vibrate and as a proximate result of such vibration the person or property of a neighboring owner is injured, such injury should be compensated in damages. Taking into consideration the fact that the use of explosives is positively necessary for the discovery of mineral structure by this method, that such operations are not continuous, and that damage by vibration is of occasional occurrence, a court should not enjoin the use of the seismograph but leave the injured party to his remedy in damages.

\section{B. DAMAGES}

The damages which should be awarded once liability is determined may present an interesting problem. The landowner wishing for complete restoration of his property may well be asking for the impossible. Strata damaged by seismic explosions generally are unable to provide an uncontaminated water supply equal to that obtained prior to the damage. On the other hand, the new well drilled to a greater depth may produce a far greater amount of water than that previously obtained.

The difficulties in awarding damages may best be illustrated by a hypothetical problem. Farmer $\mathrm{X}$ owns a four section farm with only one source providing an adequate supply of water. This source is destroyed and the action is commenced and completed before the well on the property is repaired or a new well drilled. What is the measure of damages? Farmer $\mathrm{X}$ may be able to drill one well and obtain an adequate supply of water, on the other hand he may drill twenty dry holes and still not obtain water in sufficient quantities to carry on his operations. In the former case the damages to the land are slight and the award to Farmer X could be small. In the latter case, however, the damages could be immense as a result of a marked depreciation in the value of the land.

20 Summers: The Law of Oll and Gas, 8. 661. 
Using trespass and flooding of lands cases as an analogy the measure of damages is not the cost of replacement but the depreciation of the market value. ${ }^{21}$ An Alberta District Court case ${ }^{22}$ had held that the injured plaintiff was entitled to have his real property completely restored even if it resulted in an improvement. The case was expressly disapproved by Freedman, J. of the Manitoba Court of Queen's Bench when, after reviewing the Alberta case, and the marine law on which it was based, concluded: ${ }^{23}$

I take it to be the law that where injury is done to real property the true measure of damage is the diminished value of the property. The cost of repairs may or may not coincide with such diminished value. At best the cost of repairs is an indirect method of ascertaining diminished value. Sometimes, however, it is a convenient and practical method to be employed. Where the repairs have the effect of restoring the property to its condition prior to the damage, the cost thereof may, and very often will, correspond with the diminished value, but even though judgment in such cases may be given in the amount expended for repairs, it is only so given because the court has found it to represent the diminished value of the property, which still remains the true yardstick. Hence, where the cost of repairs is not in line with the actual diminished value of the property - as is manifestly the case here-it cannot be safely relied on as indicating the amount of the damage.

Halsbury's Laws of England ${ }^{24}$ dealing with injury to land by nuisance or negligence states as follows:

Where injury to land is caused by nuisance, damages will be given for the loss or inconvenience actually suffered but not normally for any consequential depreciation of the selling value of the land, for if the nuisance continues damages may be recovered in successive actions by the person entitled to possession, the right to bring such actions accruing with the damage suffered de die im diem. Similarly where injury to land results from negligence the measure of damages is, as a rule, when the plaintiff is in possession, the cost of making good the damage actually done if that would be the reasonable course to take, but where it would not be reasonable to make good the damage and it is of a permanent character damages are assessed on the basis of depreciation-the depreciation in the value of the property injured.

Thus in an action for nuisance, damages could only be awarded based on the inconvenience to the landowner. It is submitted that this statement certainly does not contemplate a set of facts such as given in the preceding example, for the inconvenience to Farmer $\mathrm{X}$ could be negligible, especially if he lives elsewhere, but the damages suffered could be quite substantial. The statement as it relates to negligence would be much more applicable to the example given. It would seem that the better approach to damages for this area of nuisance would be the cost of restoration of the water supply or the cost of providing an adequate supply of water to the land damaged with further damages for any devaluation of the property. It appears from the judgment in the Reilly case that this latter method was adopted in awarding damages.

\section{EVIDENCE*}

The Courts have acknowledged a causal relation between damage to water wells and the discharge of explosives in the conduct of seismicsurveys if the damage flows directly from the discharge. Damage to a water well which occurred shortly after the discharge of explosives in the immediate area of the water well forms the basis of liability in Phillips

21 Marshall v. Woodlands R.M. and Lillies, [1947] 2 W.W.R. 97. See also Kilby v. Point Gray Mun., [1917] 2 W.W.R. 206; Dods \& Shade v. Bulman, [1948] 1 W.W.R. 545.

22 National Theater Ltd. V. Macdonald's Consolidated Ltd., [1940] 1 W.W.R. 168.

23 Regnier v. Nelson, (1956), 19 W.W.R. 36.

2411 Halsbury's Laws 268, (3d ed. Simonds 1955).

- This portion of the paper was written by Bruno J. Todesco. 
v. California Standard ${ }^{2 s}$ and in the unreported judgment of Kirby J., in the case of Reilly v. Pan American Petroleum Corporation. ${ }^{28}$

Riley, J., summarized the facts in the Phillips case as follows:

There was evidence that on October 25, 1956, the plaintiffs mother-in-law was in the kitchen of the plaintiff's home having breakfast at about the hour of 8:00 a.m. when she heard a terrific explosion which jarred the house and dishes, ... At all events, at approximately 5:30 to 5:45 p.m. on October 25, 1956 the plaintiff visited the well. He heard a gurgling sound like air in the well, drew off some two pails of water which was highly discoloured and highly odoriferous, smelling highly of sulphur and, as said by some of the witnesses, like a smell of rotten eggs.

The facts found in the Reilly case were that on the 9th day of August the defendants blew some shot holes in the general vicinity of the water well and on the 12th day of August it was discovered that the spring had stopped flowing.

In both the Phillips and Reilly decisions the cessation of flow and pollution were directly related, in point of time, to the discharge of the explosives. This factor led Kirby, $\mathbf{J}$., in the Reilly case to conclude that:

In my view the only reasonable conclusion that can be arrived at from the evidence in this case is that the shots exploded by the defendants on the 9th of August in the vicinity of the artesian spring set up vibrations which caused damage to the underground strata and as a result the artesian spring stopped flowing.

Similarly Riley, J., concluded in the Phillips case that:

The evidence is overwhelming and overpowering linking the plaintiff's loss with the defendant's explosions, the vibrations of which would extend a mile deep and horizontally for some 2400 feet ... . it is noteworthy that the quantity and quality deterioration in the plaintiff's well water commenced only after the explosions set off by the defendant. The production from the plaintiff's well was reduced almost to zero.

It would appear from the preceding cases that the mere coincidence of the occurrences is sufficient evidence to establish a causal connection. This would appear to ignore the perils of post hoc ergo propter hoc reasoning in that the courts require nothing more than simultaneity. This approach differs markedly from the decision of Rogers J., in the case of Chevron Oil Company v. Snellgrove ${ }^{27}$ where he said:

... the mere proof that an event happened, or that a certain result was possibly caused by a past event, is not sufficient proof of proximate cause.

The Court in that decision applied a standard based on reasonable probability rather than mere possibility.

Western Geophysical Company of America v. Martin ${ }^{28}$ indicates the evidence which should be taken into consideration in order to determine whether any liability will attach as a result of seismic operations. In this case the following evidence was introduced on behalf of the seismic operator:

(a) A fifteen pound charge of dynamite was detonated at a depth of fifty-five feet, at a distance of eight hundred feet from the damaged water well and six hundred feet from another water well which was not injured.

(b) The damaged water well produced from a depth of one hundred and eighty feet.

(c) The explosion was south of the water well and not in the path of the movement of the water.

(d) The explosion was not in the water sand but in the strata above the water sand.

25 (1960), 31 W.W.R. 331.

26 Ante n. 19

471.

28174 So. (2d) 706. 
(e) Approximately five days subsequent to the explosion another well was drilled to the same depth as, and ten feet from, the damaged well and such other well produced good water in abundant volumes.

(f) Evidence was introduced that charges had been fired by the Atomic Energy Commission in other sections of the State on the order of five hundred pounds of dynamite at a distance of three quarters of a mile from a water well and the well was not affected.

Brady, J. concluded that:

Viewing the testimony of the appellee objectively, we are forced to conclude that the best which can be said for the testimony is that it was possible the well damage could have resulted from a seismograph charge, but this Court has held on numerous occasions that the possibility a cause will produce a certain result is no substantial testimony at all.

He adopted the following statement from Humble Oil and Refining Company v. Pitman: ${ }^{20}$

Against this expert testimony there is left only the circumstance that soon after the charges were fired some disturbance of the well appeared. This may of course have had a causal connection with the explosions. There is plausible ground for lay witnesses to so suspect. Yet verdicts may not rest upon suspicion or conjecture. In its last analysis the circumstantial evidence adduced to support the verdict is the theory post hoc ergo propter hoc. This basis has never of itself been held substantial enough upon which to erect proximate causation.

In conclusion it would appear that the Phillips and Reilly cases reach a predictable result on their particular facts, but as precedents should be limited to cases where water well damage and the explosion of seismic charges are directly related in point of time. Where such a relationship does not exist it would be dangerous to draw inferences as to causal relation based on mere possibility. The difficulty of proving a causal relation should in no way diminish a claimant's obligation to establish causal relation by competent evidence.

\section{CONCLUSION}

Liability for subsurface damage from seismic operations may arise through the application of more than one rule of law. Different jurisdictions have dealt with the problem using different causes of action; among which are included negligence, trespass, the rule of Rylands v. Fletcher and nuisance.

In Western Canada nuisance has been accepted as the most suitable cause of action, the courts leaning towards strict liability rather than specific proof of negligence on the part of the defendant. Little evidence is required to establish the essential facts: seismic explosions, and damage to the plaintiff's property shortly thereafter. It appears that the Courts in these jurisdictions will infer causation once these two essential facts have been established.

\section{DISSEMINATION OF MATERIAL AND RELATIONSHIP OF THE PARTIES*}

In the course of carrying out a seismic survey, $G$ inadvertently shoots Z's adjoining leases. The results of the shooting of Z's leases indicate that the leases do not contain the geological structure that is currently of interest in the area. G informed $X$, to whom he owed a favour, that he had had a look at the seismic records and that the lease looked to him to be on formation, and, as a result, $\mathrm{X}$ completed a deal with $\mathrm{Z}$ whereby

29210 Miss. 31449 So. (2d) 408.

This portion of the paper was written by Donald C. Hetland. 
he purchased a half interest in Z's leases for $\$ 50,000.00$. Has $X$ any claim against $G$ now that it is established that the seismic records indicate that these leases are off structure?

\section{A. NEGLIGENT STATEMENTS}

Until recently, English jurisprudence did not recognize a duty of care with respect to negligent misrepresentation in the absence of a breach of fiduciary or contractual duty towards the representee. The case Derry v. Peek ${ }^{30}$ decided that fraud must concur with a false statement in order to give a cause of action in tort. Years later, the case Nocton v. Lord Ashburton, ${ }^{31}$ considering the duty of care for negligent misrepresentation, found that the fiduciary relationship between a solicitor and client created a duty of care for statements made to the client. The majority decision of the English Court of Appeal in the case Candler v. Crane, Christmas $\& \mathrm{Co}^{32}$ decided in 1951, reaffirmed that the categories of negligence were not to be extended to make a person liable for negligent misrepresentation outside the bounds of a contractual or fiduciary relationship.

In the Candler case, a limited company engaged the defendant, an accounting firm, to prepare a financial statement as to the company. The defendant knew that the statement would be used for the purpose of inducing the plaintiff to invest money in the company. The defendant was careless in preparation of the statement, and as a result, the financial standing of the company as represented therein was misleading. Relying on the statement, the plaintiff invested in the company and suffered financial loss when it failed. The majority decision of the English Court of Appeal found no duty of care owed by the plaintiff to the defendant with respect to the negligent misrepresentation. However, Lord Justice Denning, in his dissenting judgment, observed that the categories of negligence are never closed, and held that knowledge by the defendant that the statement was for use by the plaintiff who relied upon the skill of the defendant, created, under the circumstances, a relationship of proximity that imposed upon the defendant a duty to take reasonable care as to the accuracy of the statement.

Subsequently, in the leading English case Hedley, Byrne \& Co. v. Heller \& Partners Ltd. ${ }^{33}$ the House of Lords unanimously disapproved the majority decision in the Candler case and adopted the reasoning in the dissenting judgment of Lord Justice Denning.

The plaintiffs, Hedley, Byrne \& Co., through their own bank inquired from the defendant bank as to the credit-worthiness of one of the defendant bank's customers, a limited company with whom the plaintiffs were dealing. The information provided by the defendant bank was qualified as "given without responsibility". The plaintiffs relied upon the information given and as a result, suffered financial loss when the company went into liquidation. The plaintiffs sought recovery from the defendant for damages on the ground that the information was negligently given and in breach of the defendant's duty to exercise care in giving it.

Although the plaintiffs did not succeed in their action because the defendant bank had qualified its information as being given "without

30 [1889] 14 A.C. 337.

31 1914 A.C. 932.

32 1951 1 Ail E.R. 426

33 [1963] 2 All E.R. 575 . 
responsibility", the House of Lords clearly stated that the circumstances were such that the defendant bank had a duty of care with respect to the information provided for the use of the plaintiffs, who were not its customers.

The Hedley Byrne case was considered by the British Columbia Court of Appeal in the recent case, Mutual Mortgage Corporation Ltd. v. Bank of Montreal and Burnie. ${ }^{34}$ In the latter case, the plaintiff was a mortgage company wholly owned by its manager named Korsch and the defendant Burnie, a branch manager of the defendant Bank of Montreal. A customer of the defendant bank was Hy-Grade Woodworking Co. Ltd. which attempted to obtain additional financing from the bank. Burnie advised Hy-Grade that the bank refused to extend further credit but said that he might be able to secure a loan to Hy-Grade from another source. Burnie then got in touch with Korsch and as a result of their discussions, Korsch lent money to Hy-Grade. In due course, Hy-Grade became insolvent and the plaintiff was unable to secure repayment of his loan. The plaintiff then commenced an action against the defendants, claiming, inter alia, negligent misrepresentation.

Davey, J. A., in a dissenting judgment, found for the plaintiff against the defendant Burnie, basing his decision on the principle of the Hedley Byrne case. He said:

That brings me back to the primary question of whether Burnie committed any breach of duty in the information that he supplied. For this purpose I accept Hedley Byrne \& Co. v. Heller \& Partners Ltd., supra, as binding upon this court, until the Supreme Court of Canada deals with the subject authoritatively. ... By supplying Korsch, under those circumstances, with information material to the loan, Burnie accepted the duty to use reasonable care to see that the information he did supply was accurate, at least to the extent of matters within his own knowledge: Hedley Bryne \& Co. v. Heller \& Partners Ltd., supra.

The judgment of Sheppard, J.A., quotes the headnote of the Hedley Byrne case as follows:

If, in the ordinary course of business or professional affairs, a person seeks information or advice from another, who is not under contractual or fiduciary obligation to give the information or advice, in circumstances in which a reasonable man so asked would know that he was being trusted, or that his skill or judgment was being relied on, and the person asked chooses to give the information or advice without clearly so qualifying his answer as to show that he does not accept responsibility, then the person replying accepts a legal duty to exercise such care as the circumstances require in making his reply; and for a failure to exercise that care an action for negligence will lie if damage results.

Sheppard, J.A. went on to say:

Under such statement, the duty of care requires the plaintiff to establish: (a) That in the ordinary course of business the plaintiff sought information or advice from the defendant; and (b) Under circumstances that a reasonable man in the position of the defendant would know that his skill or judgment was being relied upon.

Sheppard, J. A., found that the findings of fact by the trial judge did not fit the rule in the Hedley Byrne case because the transaction was not in the ordinary course of business of the bank and that a reasonable man in the position of the defendant bank or its local manager would not know that the advice was being relied upon.

Lord, J.A., held that the findings of fact by the trial judge failed to show any negligence on the part of the defendants. 
The facts of the problem at hand are not given in sufficient detail to determine whether $\mathrm{X}$ could establish circumstances giving rise to a duty of care or whether G's statement was negligent or whether a reasonable man in the position of $G$ would know that his skill and judgment was being relied upon. Suffice to say, that the House of Lords has considered the rule in the Hedley Byrne case necessary to meet the needs of modern society. On this point Lord Pearce said:

How wide the sphere of the duty of care in negligence is to be laid depends ultimately on the court's assessment of the demands of society for protection from the carelessness of others. Economic protection has lagged behind protection in physical matters where there is injury to person and property.

\section{B. POSSIBLE ACTIONS IN TORT*}

The purpose of this memorandum is to determine whether or not there is a cause of action against $G$ if $G$ permits the seismic records to be disclosed to $Y$ who has been negotiating with $Z$ to purchase the other half interest in Z's leases, and, by reason of $Y$ learning from these seismic records that the leases are off structure, $Y$ withdraws from the negotiations.

The question to be decided is whether or not $\mathrm{Z}$ has any claim against $G$ for the loss of the potential sale of the lease interest to $Y$. At the time of G's intervention in the negotiations between $Z$ and $Y$, there was no contract between $Z$ and $Y$ and therefore this memorandum excludes any consideration of the tort of inducing breach of contract. However, there are a number of other torts that are to be considered and these will be dealt with individually.

\section{Intentional Interference with Prospective Advantage}

There can be no doubt that $\mathrm{Z}$ anticipated that the negotiations for the sale of his lease interest would result in an economic advantage to him and that it was G's intervention that terminated this prospect. $U_{p}$ to that point both parties in the negotiations were mutually mistaken as to the real worth of the lease interest that was the subject matter of those negotiations. This mistake was due to G's misinforming $X$ and the consequent profiting of $Z$ in selling one-half of his interest to $X$.

The law with respect to the tort of interfering with prospective advantage appears today to be the same as that laid down in the case of Allen v. Flood. ${ }^{35}$ Fleming on Torts (3d ed.) sums up the situation as follows:

Not until the end of the 19th century did the view finally prevail that, in the absence of such additional factors as the use of illegal means or conspiracy (involving a combination), no liability accrues for intentionally inflicting economic loss, as by tempting or even procuring others not to do business with the plaintiff. At one time, there was some support for the broad proposition that he that hinders another in his trade or livelihood is liable to an action for so hindering him', but it is now settled that interference with economic relations, which are merely in prospect and not yet cemented by contract, is not actionable at the suit of the person disappointed.

Therefore, it would appear that if there is no conspiracy and no unlawful means used by the defendant, there is no cause of action even if the sole aim of the defendant was to cause the plaintiff pecuniary loss. There are therefore three main ingredients of the tort of interference

35 [1898] A.C. 1.

- This portion of the paper was written by John S. Moore. 
with prospective economic advantage; intent to injure the plaintiff, use of illegal means, and defacto injury.

With respect to the first of these three ingredients, it is questionable whether $G$ did in fact intend to injure $Z$. There was certainly no malice towards $\mathrm{Z}$ and it appears that $\mathrm{G}$ was merely bringing out the truth at a time before $\mathrm{Y}$ undertook to buy a worthless lease interest. The cases have held three categories that might constitute "illegal means":

(i) Nominate torts and crimes.

(ii) Threat of an unlawful act (Rookes v. Barnard (H.L.)) ${ }^{3 \mathrm{~B}}$

(iii) Technical breach of statute (International Brotherhood of Teamsters v.Therien (S.C.C.)) ${ }^{37}$

It would appear that in our fact situation the defendant has not used illegal means. As a matter of fact, all that the defendant did was to tell the truth and this constituted his intervention into the negotiations.

With respect to the third ingredient for the tort, it is questionable whether or not the plaintiff actually suffered injury from the defendant's actions. G's intervention merely removed the mistake that had clouded the atomsphere of the negotiations and left the parties in the situation based on the facts with respect to the lease interest that were actually in existence. In other words, G's intervention merely put $Z$ in the position in which he should have been all along. The word "injury" seems to connote leaving an individual in a position of detriment somewhat below what would otherwise be his position in the ordinary set of events. The intervention of $G$ then reduced $Z$ 's position from a point above the norm to the norm rather than reduce his position from the norm to a point less than the norm and, in the opinion of the writer, only the latter is a fair interpretation of the word "injure".

Getting back to the other factor (besides illegal means) which the quotation above from Fleming indicates must be present in order to constitute a cause of action in accordance with the law as laid down in Allen v. Flood, ${ }^{38}$ namely, conspiracy, there appears to be no evidence of any combination in the fact situation before us. Even if there was, in view of the case of Crofter Hand Woven Harris Tweed v. Veitch, ${ }^{30}$ the judgment indicates that combination to injure is prima facie actionable unless justified and the Crofter case sets the test for justification as being the purpose (rather than the consequences) of the activity and in our fact situation the purpose was to prevent $Y$ from entering into a contract to his detriment rather than any purpose to injure Z-injury to $\mathrm{Z}$ (if there was any) was merely a consequence of the conduct and not the purpose.

\section{Intimidation}

As a result of the cases of Rookes v. Barnard and the Therien case ${ }^{40}$ it is clear that there is a tort known as intimidation. However, to constitute such a tort it is necessary to show that the defendant coerced a person by threats of violence or other illegal action into doing or abstaining from doing something that he would otherwise have every right to

\footnotetext{
36 [1964] 1 All E.R. 367.

37 [1960] S.C.R. 265

88 Ante, n. 35

39 [1942] A.C. 435.

so Ante, n. 36, 37.
} 
do, ${ }^{41}$ such as hiring a particular employee or ceasing to do business with an old customer. In other words, it would have to be shown that G coerced $Y$ by threats of violence or other illegal action into dropping the negotiations for the purchase of the lease interest from $Z$. Although "illegal action" has received very broad interpretation to include even statutory misdemeanors and, in the Therien case, a breach of contract, it would seem unlikely that the conduct of $G$ in our fact situation could constitute anything but a lawful act since it was merely a disclosure of the truth.

\section{Slander of Title or Injurious Falsehood}

According to Fleming on Torts, ${ }^{42}$ in order to establish a cause of action, there must be a publication of a false statement concerning the plaintiff's property calculated to induce others not to deal with him. In other words, the statement must be false (not the situation in our case), it must be published with malice, and actual damage must occur to the plaintiff. Fleming points out that if the statement is true the law withholds its protection, because it apparently sees no reason for deterring publication of the truth even when it is made solely for the purpose of doing harm.

Could, however, the false statement made by $\mathbf{G}$ to $\mathrm{X}$ give rise to a cause of action for $Z$ ? In that case, the statement was actually false, it was made with "malice" since malice is usually defined as "without just cause or excuse" (per Scrutton L.J. in Shapiro v. LaMorta) ${ }^{\text {t3 }}$ but, if damage or injury is the gist of this tort (as Fleming indicates on page 674) there is the argument presented above with respect to whether or not $\mathrm{Z}$ has actually suffered injury. On page 672, Fleming makes the following remarks:

\section{.... injurious falsehood cannot succeed unless the plaintiff is able to prove that he sustained actual economic loss, that the offensive statement was false and was made with intent to cause injury without lawful justification.}

One of the elements that may perhaps be missing when we consider this tort, vis-a-vis the statement made to $X$, is the intent to cause injury. It would seem to be very difficult to show that it was, at the time the statement was made, the intention of $G$ to injure $Z$. As a matter of fact at the time that the statement was made, one could just as easily say that the intent was to benefit $\mathrm{Z}$ since that is exactly what happened when $\mathrm{Z}$ was able to sell one-half of his lease interest to $\mathrm{X}$ at a price inflated due to the false statement. Therefore, if one looks at the first statement made by $G$ one comes to the conclusion that it was not made intending any injury to $Z$, and, as a matter of fact, it benefited $Z$. When one looks at the second statement made by $G$ one comes to the conclusion that it was not a false statement. This therefore leads to the question of whether the two statements taken together could result in a cause of action for Z. Combination of the two is what led to Z's loss of a prospective economic gain. In the writer's opinion these facts still do not indicate a cause of action for two reasons already expressed, namely, that there was not any actual damage and that there was an absence of intent on the part of $G$ to deliberately injure $Z$.

41 Fleming on Torts, 3d ed., at 662.

42 Id., at $671-3$. 
4. Deceit

This tort is much the same as the previous one in that they both deal with false representations. Fleming distinguishes between the tort of injurious falsehood and the tort of deceit as follows:

Unlike the wrong of deceit, which is committed by making a false statement to the plaintiff himself whereby he is induced to act to his own detriment, here (injurious falsehood) the falsehood must be communicated to a third person. ${ }^{44}$

This distinction seems to conflict somewhat with an earlier statement by Fleming on page 610:

The representation need not, however, have been made directly to the plaintiff, so long as he was intended to rely upon it, as when seller of a defective gun fraudulently warranted it to be safe for the use of the purchaser's son. But to complain of deceit, the plaintiff must have acted himself to his detriment in reliance thereon; if it merely induced others to act to the plaintiff's prejudice, the only available recourse will be for injurious falsehood, a wrong more limited in scope.

And at page 609 Fleming states:

A fraudulent misrepresentation is not actionable, unless it was made with the intent that the plaintiff should act upon it as he in fact did. It is not sufficient merely that the defendant, as a reasonable man, should have realized the likelihood that the plaintiff might rely on it to his detriment, reliance must have been intended, not merely foreseeable.

From the facts of this case it would appear that there was no intention on the part of $G$ when it made the statement that $Z$ should rely on it. Rather the facts indicate that $G$, as a reasonable man, probably realized the likelihood that $\mathrm{Z}$ might rely on it to his detriment. As well, damage is the gist of the action of deceit and the same argument made above with respect to whether or not $\mathrm{Z}$ had actually suffered damage as a result of these statements would similarly apply with respect to this tort.

\section{Trespass}

The action of trespass indicates only violence of actual possession and is not concerned with protecting the interests of persons out of possession at the time of the intrusion. However, possession (or the right to same) of a lease interest in mines and minerals is likely a sufficient title in order to ground an action for trespass. The case of Mason v. Clarke ${ }^{45}$ indicates that the grantee of a legal or equitable interest in land, such as an easement or a profit a prendre, can sue in trespass for direct intereference by strangers.

If $\mathrm{Z}$ has sufficient title in order to bring an action in trespass, and if $G$ has in fact carried out seismic work and thereby intruded upon the interest held by $Z$, it would appear that $Z$ has a cause of action regardless of whether or not the intrusion by $G$ was inadvertent.

Intentional invasions are actionable whether resulting in harm or not. Neither the intruder's motive is material nor the fact that his entry actually benefited the occupier. The requisite intent is present if the defendant desires to make an entry, although unaware that he is thereby interfering with another's right. Thus, it makes no difference whether the intruder knows his entry to be authorized or honestly and reasonably believes the land to be his. It may, however, affect the quantum of damages. In cases of mistakes where no perceptible damage is done, only nominal damages are awarded, yet the verdict against the defendant is justified in order to defeat his adverse claim to the land. If on the other hand actual damage has occurred, as when A believing B's land to be his cuts a stand of timber or works a seam of coal, the award no more 
than compensates the plaintiff for the loss he has suffered as a result of the unauthorized entry. 10

If $\mathrm{Z}$ does have a cause of action in trespass against $\mathrm{G}$ then the question becomes one of ascertaining what measure of damages a Court is likely to award. The above quotation from Fleming seems to indicate that exemplary or punitive damages would not be awarded in the case of an inadvertent trespass and that the damages would be confined to the actual loss or damage suffered by the plaintiff. If this is true, we are left with the question of whether or not $\mathrm{Z}$ has actually suffered damage and this particular matter has been discussed above. As far as physical damage is concerned, there would seem to be none whatsoever-as to the leasehold interests in the minerals. On the other hand, it is the surface owner, if anybody, who has suffered actual physical damage. It is therefore the writer's opinion that at the most, there would only be nominal damages awarded to the plaintiff for a technical trespass of his interest in the land.

\section{CONCLUSION}

It is doubtful whether any liability attaches to a party disclosing seismic information where there is no contractual or fiduciary relationship between the parties. It would appear that no duty arises where the party discloses information voluntarily and for no benefit of his own. In most instances, a cause of action would only arise where intent to injure could be shown on the part of the defendant. If there is an intent to injure several torts may have been committed. These include; intentional interference with prospective advantage, intimidation, deceit and slander of title or injurious falsehood. 